\title{
Analysis of Sedimentation Rates in the Densu River Channel: The Result of Erosion and Anthropogenic Activities in the Densu Basin
}

\author{
J. M. Kusimi \\ Department of Geography and Resource Development, University of Ghana, P. O. Box LG59, \\ Legon, Accra, Ghana \\ Email:jmkusimi@ug.edu.gh/jmkusimi@yahoo.com
}

\begin{abstract}
Sediment is important in determining the morphology of river systems. The Densu basin has come under intense anthropogenic activities such as farming, sand winning, bushfires, among others, which are impacting on the fluvial processes, forms and channel morphology of the river. The study investigated sedimentation of the river channel in the light of these human activities along its banks. Fluvial processes include erosion and deposition particularly at the lower and middle courses, which is fashioning the morphology of the river channel. Data on river sedimentation was determined through sediment load analysis. The results of bed load show well-graded particles, particularly results of low flows throughout the river's course. Generally, the percentage of coarser materials (gravels, sediments $>5 \mathrm{~mm}$ ) was low, while the percentage of sand in the bed material was high in all the stations at high flows, over $80 \%$ in Ashalaja, $70 \%$ in Mangoase and moderate at Akwadum (about 50\%). Clay particles were low or absent in the sampled stations during high flows. Fluvial sediment transport for suspended load during high flows was high and low for the low stages. The highest suspended sediment discharge was 475.641 tonnes/day at Akwadum at $2.18 \mathrm{~m}$ and the lowest was 0.492 tonnes/day at $0.53 \mathrm{~m}$ also at Akwadum. Sediment discharge increased downstream from Akwadum to Ashalaja at both low and high flows, which was attributed to a number of variables such as a reduction in vegetative cover and increase in discharge downstream. The middle course experienced active channel erosion whilst deposition (channel braiding) was prevalent at the lower course.
\end{abstract}

\section{Introduction}

Human-induced modifications of vegetative cover in river basins may cause strong geomorphic responses by disturbing sediment supply, transport and deposition regimes. The movement of sediments in river valleys shapes the course of the river and nature of its channel. Definition of long-term sediment load, concentration and particle size distribution are important in the design of dams, pipes, canals, bridges, water treatment processes and in the evaluation of quality of water problems (Ayibotele \& Tuffour-Darko, 1979).

Sediment transport is basically in two forms, bed load and suspended load. Bed load sediments are those that are transported by saltation, traction, rolling or sliding on, or close to the river bed, whilst suspended load is sediment in suspension by the upward components of turbulent currents. The amount of load carried in suspension by a river mainly depends on the volume and velocity of the stream, the nature and size of weathered material available, the vegetative cover and the character of the stream bed. The underlying process of fluvial sediments is erosion, which is a function of climate, vegetation, soil characteristics and topography.

For the past two decades, the Densu River has been subjected to numerous environ-mental threats such as farming, urbanization, logging and animal grazing along its banks particularly at Nsawam, Weija and Oblogo. Vegetables (e.g. okra), sugarcane, papaya and pineapples are extensively cultivated on commercial basis on the $35 \mathrm{~m}$ buffer zone regulation of the river. The $54.32 \mathrm{~km}^{2}$ restricted zone demarcated under the Executive Instrument 130 of 1977 for the Weija lake has been seriously encroached upon according to the recent government committee report (Akuffo, 2003). These activities have reduced the vegetative cover, making soils more vulnerable to erosion into the river, which has serious implications on channel morphology and sedimentation of the Weija Reservoir.

The river channel, especially the middle and lower courses are seriously experiencing erosion and siltation which is threatening the existence of the Weija Dam. The lake is silting up at a rate of 
$2 \%$ per year, giving it a lifespan of 50 years and is already 27 years old, meaning it has 23 years life left in it (Akuffo, 2004), if no stringent measures are taken to curb this situation. The degradation of the basin is attributed to the increase in the population of districts through which the river flows, particularly in the Greater Accra Region. For instance, the population of Accra has increased from 903,557 in 1970, to 1,431,099 in 1984 and 2,909,643 in 2000 (Ghana Statistical Service, 2002), and this has led to an increase in demand for housing, water, food and other resources of the basin. This accounts for the encroachment of the floodplain at Weija, a wetland declared as a RAMSAR site, for housing, farming and other human activities.

The study focused on the hydrological implications of these environmental activities of man on sediment yield and channel morphology of the Densu basin. These included a determination of sediment concentration, sediment transport, and the establishment of sediment rating curves for Ashalaja, Mangoase and Akwadum.

Study area

\section{Materials and methods}

The Densu basin lies between latitudes $5^{\circ} 30^{\prime} \mathrm{N}$ to $6^{\circ} 20^{\prime} \mathrm{N}$ and longitudes $0^{\circ} 10^{\prime} \mathrm{W}$ to $0^{\circ} 35^{\prime} \mathrm{W}$. The basin area is about $2488.41 \mathrm{~km}^{2}$ with an average length of $225.6 \mathrm{~km}$. Its main tributaries are the Kuia, Adaiso, Mame, Suhyen, Nsaki and Aprapon (Fig. 1). The Densu basin passes through three regions, namely Eastern, Greater Accra and Central regions, and falls under 10 district administrations. The Eastern Region has seven districts in the basin, namely East Akyem, West Akyem, New Juabeng, Suhum-Kraboa-Coaltar, Akwapim North, Akwapim South and Yilo Krobo. The Greater Accra has two districts within the basin. These are the Ga District and Accra Metropolitan Area. Part of the Awutu-Efutu-Senya District of the Central Region also falls within the basin.

Most of the urban centres such as Koforidua, Nsawam, Suhum (Fig. 1), among others, depend on the river for treated water supply. From its reservoir at Weija, 91,000 $\mathrm{m}^{3} /$ day is pumped to supply about 340,000 people in western Accra (Ghana Water Sewerage Company, 2003). Other small settlements such as Kukua, Akraabu and Aboatunpan also depend on untreated water from the Densu river and its tributaries. The Densu basin is also intensively used for the cultivation of both cash and food crops. Principal food crops cultivated within the basin are cassava, maize, yam, plantain, banana and cocoyam. Cash crops include cocoa, oil palm, papaya, pineapple, mangoes and citrus.

The Densu basin falls under two climatic regions, namely the wet semi-equitorial northern zone and the dry equatorial coastal belt. The northern part of the basin receives a mean annual rainfall between $1250 \mathrm{~mm}$ and $2000 \mathrm{~mm}$. At the coastal belt mean annual precipitation is about 740-890 mm (Dickson \& Benneh, 1988). The rainfall characteristically occurs in heavy thunder-storms, which is sometimes accompanied by squally winds. 


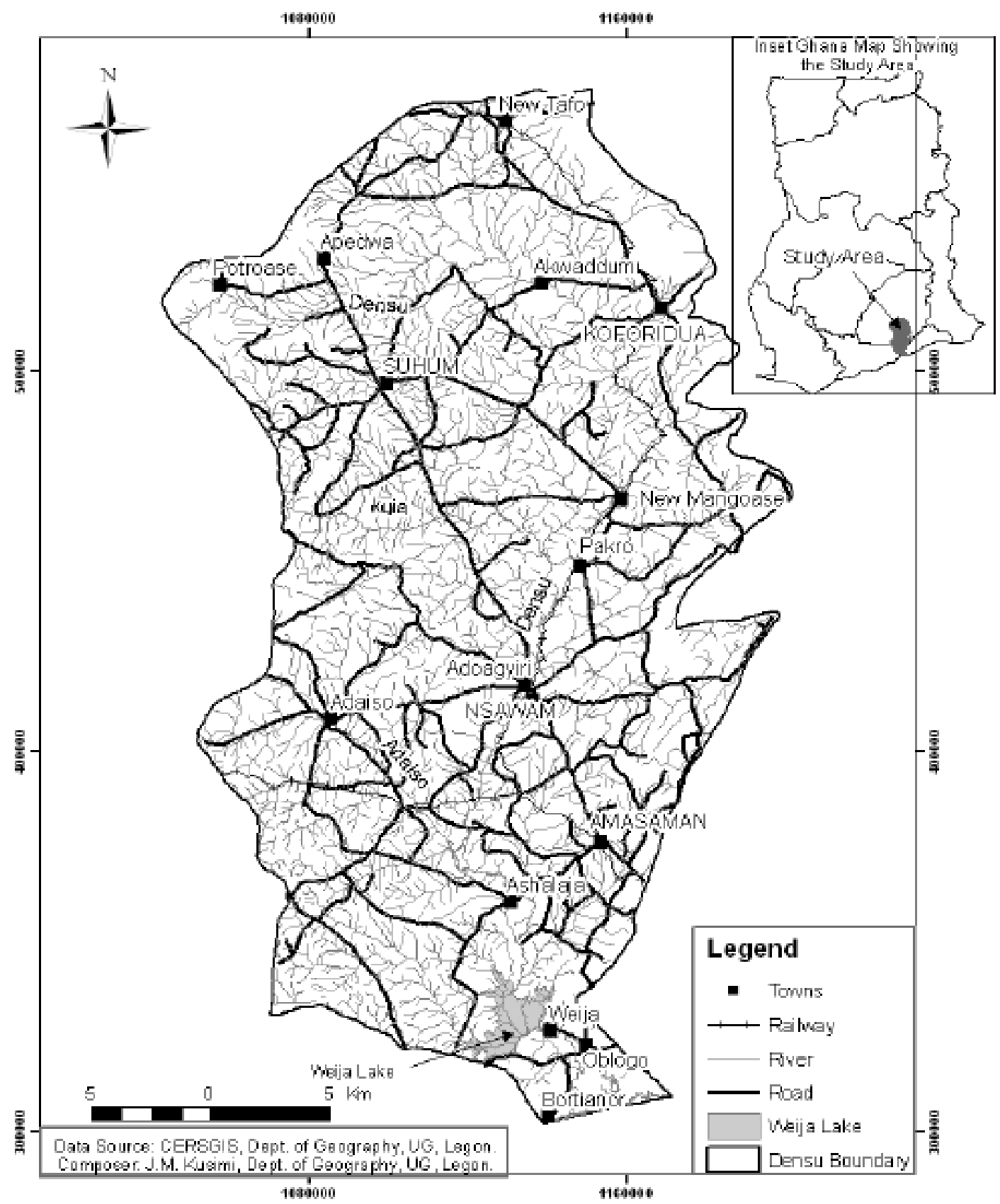

Fig. 1. Map of the Densu Basin

Soils of the Densu basin are weathered and metamorphosed materials of Precambrian rock units made up of Dixcove and Cape Coast granite complex, birimian super group and the Togo series. Adu \& Asiamah (1992) have classified the soils of the basin into four associations, each of them sub-divided into series. These are Adawso-Bawjiasi/Nta-Ofin compound association, NyanaoOpimo compound association, Nankese-Koforidua compound association and the Atewa-PikiBirim compound association.

Most of these soils are fertile due to the high organic matter content derived from the vegetative cover, but they easily loose their nutrients when exposed or cleared for cultivation due to high rainfalls and temperature. These conditions promote active chemical weathering processes, fast decomposition of organic matter and leaching. The soils are mostly reddish, yellowish or greyish West African Journal of Applied Ecology, vol. 14, 2008 
sandy and clayey derived from weathered quartz and feldspar. Their reddish and greyish colour is due to hydration of the minerals especially in the wet semi-equatorial climatic zone. The other minor formations are the Accraian and Dahomeyan, forming the coastal basement of Accra.

The Densu basin is made up of four vegetation belts, namely the wet semi-deciduous forest (northern catchment), coastal thicket, grassland, and strand and mangrove along the coast. The wet semi-deciduous forest contains most of the country's valuable timber and other tropical plants. Many of the trees in this zone exhibit deciduous characteristics during the dry season when the influence of the harmattan is much intense. Due to the rapid expansion of the cocoa industry and farming within this vegetation belt, very little of the original forest remains, and much of what is left is secondary forest (Fig. 2), (Dickson \& Benneh, 1988).

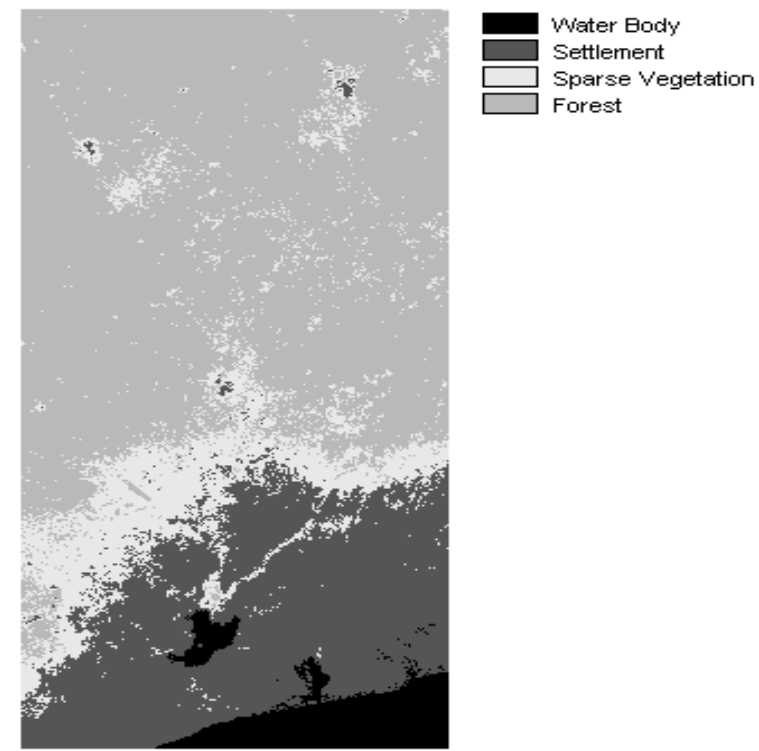

Fig. 2. Land cover/use types from NDVI Module of the Densu basin Source. Land TM 2000 Imagery (Bands 3 and 4)

The coastal scrub and grassland consists of dense scrub without grass west of Accra, and mainly grass with isolated patches of scrub and trees east of Accra, from Weija to the mouth at Bortianor. This vegetation is a degraded dry and open semi-deciduous forest (Dickson \& Benneh, 1988).

\section{Data collection and analysis}

Normalized difference vegetation index (NDVI) was employed in assessing the current biomass or plant production using Landsat TM 2000 imagery of the study area. With Landsat TM, the NDVI is obtained by deriving the ratio of near infrared and red bands as:

$$
\begin{aligned}
\mathrm{NDVI}_{\mathrm{TM}}= & \mathrm{TM} 4-\mathrm{TM} 3 \ldots \ldots . .(1.0), \\
& \mathrm{TM} 4+\mathrm{TM} 3
\end{aligned}
$$

where TM4 = Reflectance in the near-infrared band (NIR), and TM3 = Reflectance in the red band, (Jensen, 1996). The NDVI was determined using VEGINDEX Module within IDRISI Kilimanjaro image processing software. RECLASS Module was ran on the NDVI values to prepare a mask (Boolean) image of the following land cover and land use types (settlement, forest, water body, sparse vegetation, Fig. 2).

Discharge data at Akwadum, Mangoase, and Ashalaja were used to establish rating curves for the respective stations for sediment load determination. The rating curves were produced by plotting discharge against gauge heights on a log-log graph using Microsoft Excel software.

Sediment load analysis of the basin was done to determine sediment concentration and transport at Akwadum, Mangoase and Ashalaja. The stations were chosen within the three main sections of 
the river, upper, middle and lower courses. The choice of these sites were also guided by the fact that they are gauged stations of the Hydrological Services Department (Accra) which made discharge data available for the establish-ment of the rating curves. Both suspended and bed loads were measured. Samples were taken from May ending to August ending so as to catch both low and high flows. A total of 30 suspended and four bed load samples were collected at each station. Analyses were done in the Sediment Laboratory in the Water Research Institute (WRI) of the Council for Scientific and Industrial Research (CSIR), Accra.

Bed load samples were collected by means of the Van Veen Bottom Grab sampler (Ayibotele \& Tuffour-Darko, 1979). Samples were taken at midstream and river banks. Four samples were taken at each sampling station, two each for high (June) and low (August) flows, respectively. Samples were air-dried and sieved using a shaker through sieves of apertures ranging from $5 \mathrm{~mm}$ to 0.05 $\mathrm{mm}$. Tare weights of sieves were taken and the amount of sediment left on each sieve determined after sieving. The percentage of sediment remaining and that passing through each sieve was then calculated. The percentage of sediments passing through each sieve was plotted against sieve apertures on a semi-logarithmic paper using Microsoft Excel software to find out granulometric texture of the sediments.

For suspended load, three samples were taken on each sampling day to determine sediment concentration and transport. Two samples were taken midstream (one close to the riverbed, the second mid depth) and the third at the river's bank on a bridge using the Vertical water sampler (Ayibotele \& Tuffour-Darko, 1979). Water temperature was taken with a thermometer and the gauge height read at the time of sampling to determine discharge. Samples were analyzed in the Sediment Laboratory of the WRI of CSIR, Accra.

The gross weight of each sample (sampling bottle plus content) was taken with a chemical balance and nitric acid added and left for two or more days for sediments to coagulate. Water in each sample was decanted, and sediments at the bottom of the sampling bottle thoroughly shaken and then emptied into glass dishes of known tare weights. Tare weights of sampling bottles were then taken. The weight of the total sample was found by deducting tare weights of sampling bottles from gross weights. The glass dishes were oven dried at $114^{\circ} \mathrm{C}$ for an hour. The gross weights of the glass dishes were taken after cooling in a desiccator. The tare weights of dishes were deducted from gross weights to obtain sediment weight of each sample. The weight of each sediment was divided by the weight of the water-sediment mixture and then multiplied by one million, converting it to parts per million to obtain sediment concentration of the sample. Samples at each point interval were added to obtain total sediment concentration for that cross section in milligrams per litre (Ayibotele \& Tuffour-Darko, 1979).

Since sufficient daily concentra-tion data of the various stations were available, Temporal concentration graph method was employed in determining daily mean sediment discharge in tonnes per day according to the following formula:

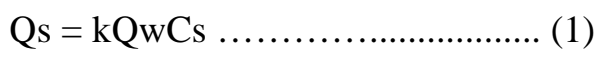

where $\mathrm{Q}_{\mathrm{s}}=$ Sediment discharge (tonnes/day), $\mathrm{Q}_{\mathrm{w}}=$ Daily mean water discharge $\left(\mathrm{m}^{3} / \mathrm{sec}\right), \mathrm{C}_{\mathrm{s}}=$ Daily mean concentration of suspended sediments $(\mathrm{mg} / \mathrm{l}), \mathrm{k}=0.0864$, a conversion factor assuming a specific weight of 2.65 for sediment (Osten, 1979). The daily mean water discharge was obtained from trend line equations of established rating curves of the respective stations since the value of $\mathrm{R}^{2}$ is about $97 \%$.

\section{Bed load}

\section{Results and discussion}

Bed load graphs are shown below, (Fig. 3-5). The curves indicate that bed load materials are well graded especially those of low flows in all the stations. Generally, the percentage of coarser 
materials (gravels, sediments $>5 \mathrm{~mm}$ ) was low, about $0.71 \%$ as the lowest in Mangoase and 22.91\% as the highest in Akwadum. This implies that much of the bed load (gravel) is either weathered or deposited (hydraulic sorting) as the materials are being transported downstream. These findings agree with literature that particle size (D) decreases with distance downstream (L), under the relationship $D=D_{0} e^{-a l}$, where $D_{0}$ is the initial grain size at $L=0$ (Knighton, 1998). Also, according to Bloom (1998), sediment concentra-tion in humid regions decreases towards a river's mouth because of deposition downstream. The high rate of weathering is due to increase in discharge downstream (Tables 1-3). Also, the wet and warm climate of the region promotes chemical weathering.

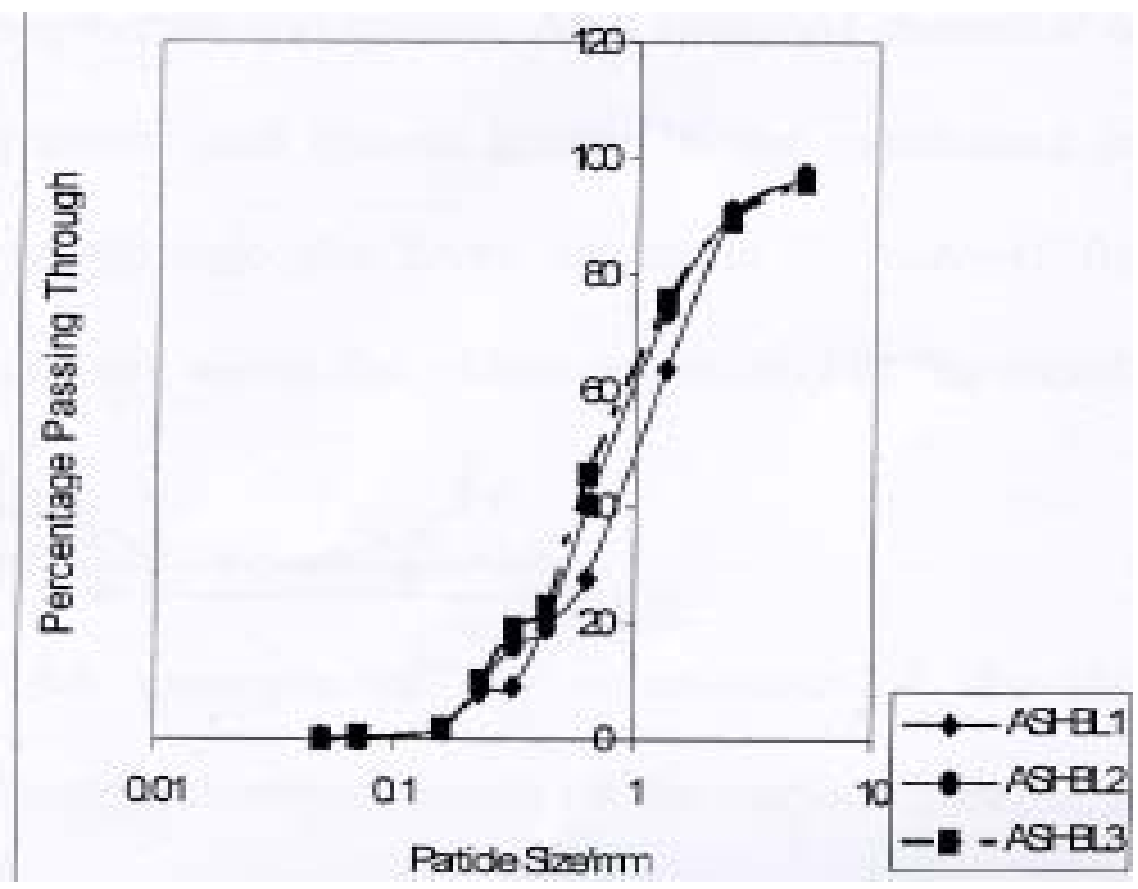

Fig. 3. Curves of bed load samples at Ashalaja

Source: Fieldwork, 2003.

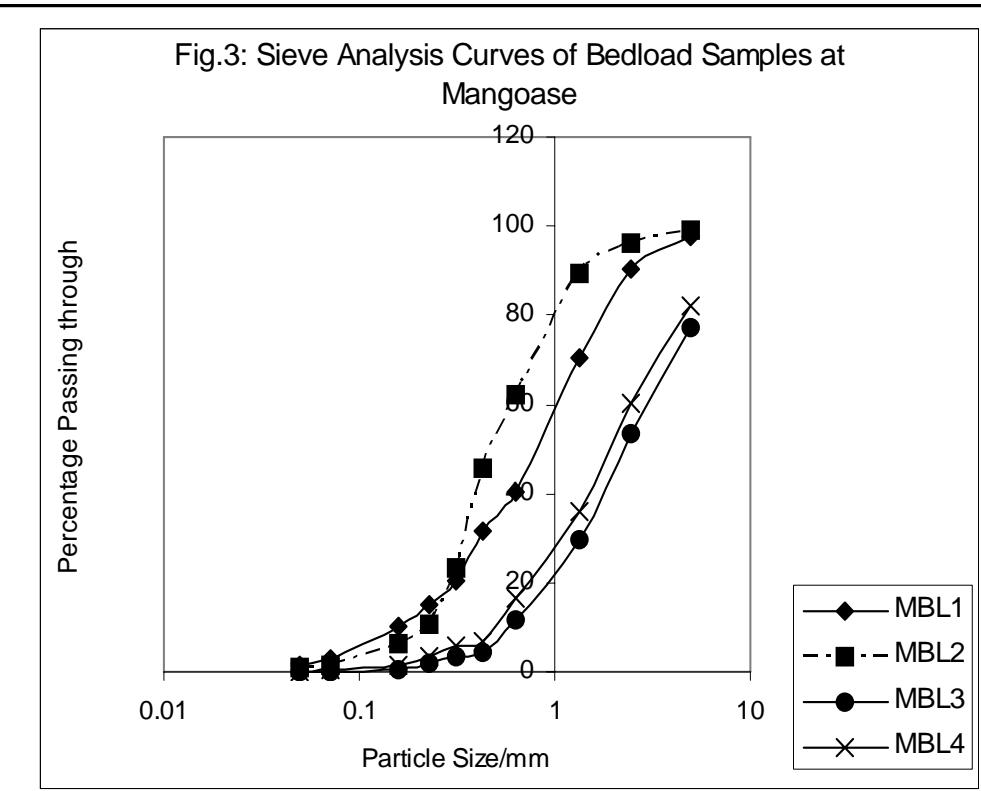

Source: Fieldwork, 2003.

Fig. 4. Curves of bed load samples at Akwadum 


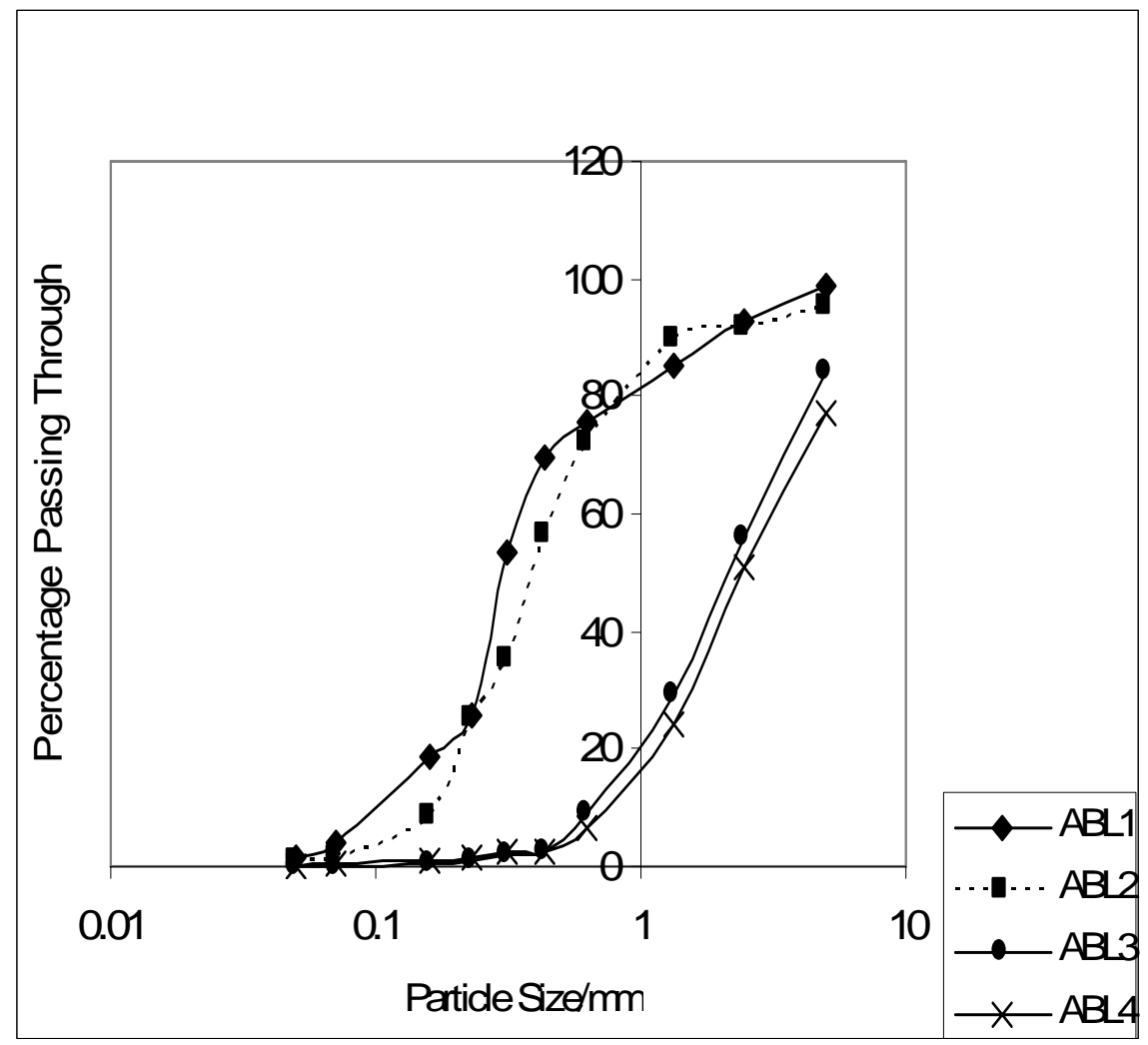

Fig. 5. Curves of bed load samples at Akwadum Source: Fieldwork, 2003.

TABLE 1

Data sheet for sediment transport for Ashalaja

$\begin{array}{lccccccccc}\text { Sample } & 01 & 02 & 03 & 04 & 05 & 06 & 07 & 08 & 09 \\ & & & & & & & & & \\ \text { Gauge height/m } & 2.48 & 2.76 & 2.37 & 0.90 & 0.785 & 1.19 & 1.30 & 1.24 & 1.06 \\ \text { Discharge/m } / \mathrm{s} & 18.644 & 23.774 & 16.817 & 1.863 & 1.366 & 3.514 & 4.296 & 3.859 & 2.702 \\ \text { Sediment conc./mg/l } & 56.39 & 59.11 & 154.28 & 108.407 & 36.896 & 468.755 & 107.05 & 144.001 & 162.24 \\ \text { Sediment transport/ } & 90.833 & 121.417 & 224.171 & 17.450 & 4.353 & 142.335 & 39.738 & 48.013 & 37.877\end{array}$

TABLE 2

Data sheet for sediment transport for Mangoase

\begin{tabular}{|c|c|c|c|c|c|c|c|c|c|}
\hline Sample & 01 & 02 & 03 & 04 & 05 & 06 & 07 & 08 & 09 \\
\hline Gauge height/m & 3.20 & 2.56 & 2.36 & 0.83 & 0.88 & 1.43 & 1.38 & 0.90 & 0.80 \\
\hline Discharge $/ \mathrm{m}^{3} / \mathrm{s}$ & 16.140 & 8.783 & 7.036 & 0.407 & 0.478 & 1.79 & 51.629 & 0.508 & 0.368 \\
\hline Sediment conc./mg/l & 265.32 & 21.481 & 93.94 & 80.688 & 117.466 & 465.665 & 137.47 & 87.861 & 82.787 \\
\hline Sediment transport/ & 369.976 & 16.300 & 57.103 & 2.858 & 4.847 & 4772.207 & 19.345 & 3.854 & 2.634 \\
\hline
\end{tabular}

TABLE 3

Data sheet for sediment transport for Akwadum

\begin{tabular}{|c|c|c|c|c|c|c|c|c|c|}
\hline Sample & 01 & 02 & 03 & 04 & 05 & 06 & 07 & 08 & 09 \\
\hline Gauge height (m) & 2.18 & 1.16 & 1.39 & 0.57 & 0.49 & 0.53 & 0.89 & 0.63 & 0.55 \\
\hline discharge $\left(\mathrm{m}^{3} / \mathrm{s}\right)$ & 30.572 & 3.423 & 6.413 & 0.2909 & 0.172 & 0.226 & 1.365 & 0.412 & 0.257 \\
\hline Sediment conc.(mg/l) & 180.0 & 33.47 & 85.44 & 24.316 & 45.243 & 25.216 & 84.19 & 39.841 & 81.99 \\
\hline
\end{tabular}


$\begin{array}{llllllllll}\text { Sediment transport } & 475.641 & 9.900 & 47.344 & 0.611 & 0.672 & 0.492 & 9.930 & 1.417 & 1.820\end{array}$

(tonnes/day)

The percentage of sand in the bed material was generally high in all the stations sampled during high flows, over $80 \%$ in Ashalaja, $70 \%$ in Mangoase, but moderate at Akwadum (about 50\%). The percentage of silt ranged from $8.82 \%$ in Ashalaja to $40 \%$ in Akwadum. At Akwadum the percentage of sand increased to about $79.25 \%$ during low flow stages whilst silt reduced to $0.84 \%$. The implication is that as the flow rate reduces more suspended load is deposited, thus, increasing the percentage of sand and silt deposited to the bed. As shown by the graphs, clay particles were generally low or absent in the sampling stations during high stages. It was also realized that the proportion of clay in samples reduces from the upper to the lower section of the river. This is because clay particles are generally suspended materials at high flows.

The low percentage of gravel and clay is also due to the nature of the dominant soil types Adawso-Bawjiasi/Nta-Ofin compound association, which are low in gravel and clay but richer in sand, and gritty loam soils with sparse biotite often with veins of pegmatite and quartz. As a result of chemical and mechanical weathering within the river, granites and quartz grains in the catchment are weathered to sand particles, which are entrained into the river channels by run-off from settlements, farm plots and vegetable gardens along the valley, especially at the middle section.

\section{Suspended load.}

An example of the calculation of the daily mean water discharge and sediment transport/concentration of the various sampling stations is made below using sample 03 of all the stations. Equation 1.1 is employed in the sediment concentration or transport determination.

Ashalaja sampling station. Equation of the line is $\mathrm{y}=\mathrm{Q}_{\mathrm{w}}=2.3669 \mathrm{x}^{2.2724}$, (Fig. 6), where $\mathrm{X}=$ gauge height $(\mathrm{m})=2.37 \mathrm{~m}$ (Table 1$), \mathrm{Q}_{\mathrm{w}}=(2.3669)(2.37)^{2.2724}=(2.3669)(7.1052)=16.8173 \mathrm{~m}^{3} / \mathrm{s}$, $\mathrm{C}_{\mathrm{s}}=154.28 \mathrm{mg} / \mathrm{l}$ (Table 1$), \mathrm{Q}_{\mathrm{s}}=(0.0864)\left(16.8173 \mathrm{~m}^{3} / \mathrm{s}\right)(154.28 \mathrm{mg} / \mathrm{l})=224.1711$ tonnes $/$ day

Calculated water and sediment discharge samples of Ashalaja are shown in Table 1. 


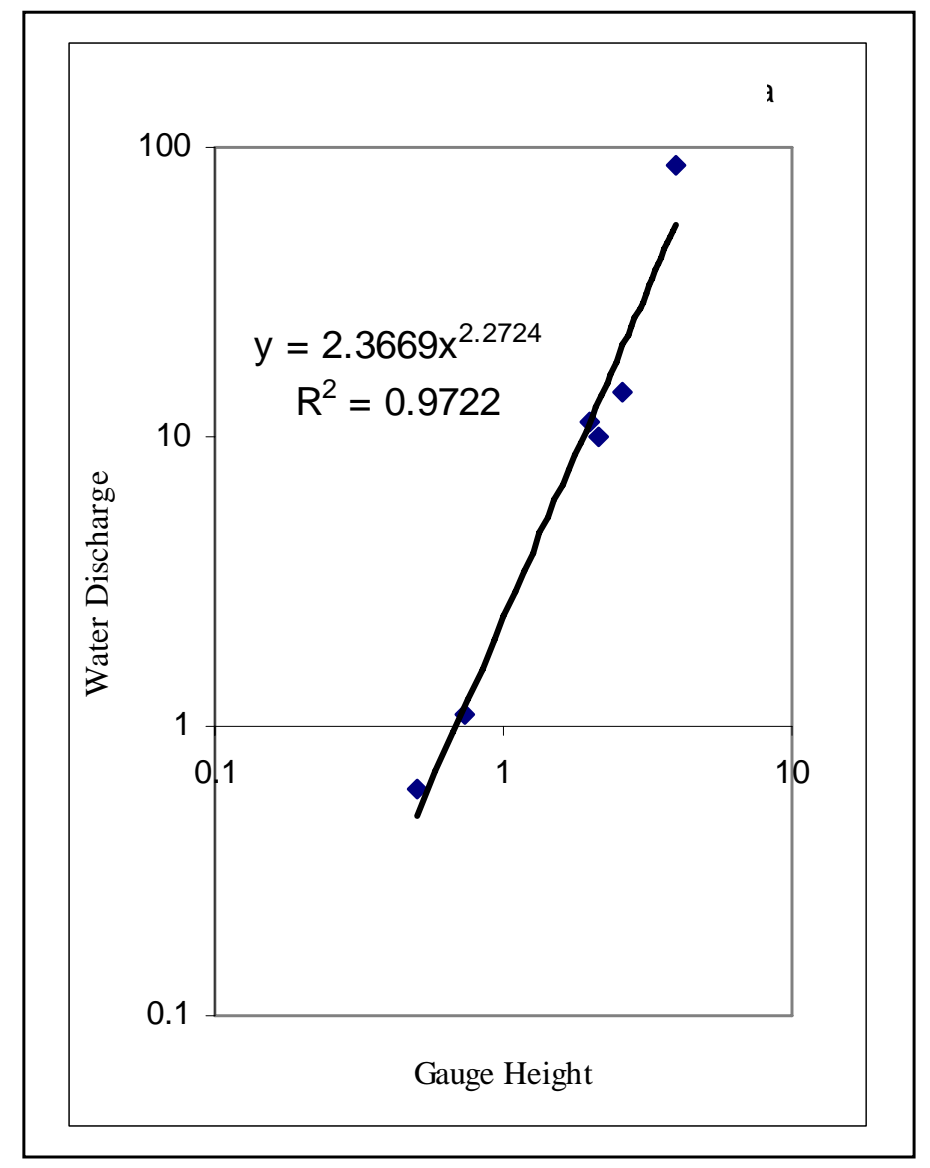

Fig. 6. Discharge rating curve for Ashalaja

Mangoase sampling station. Equation of the line is $\mathrm{y}=\mathrm{Q}_{\mathrm{w}}=0.6767 \mathrm{x}^{2.7269}$ (Fig.7) where $\mathrm{x}=2.36$ (m) (Table 2), $\mathrm{Q}_{\mathrm{w}}=(0.6767)(2.36)^{2.7269}=\left(\mathrm{Q}_{\mathrm{w}}=6767\right)(10.3967)=7.0355 \mathrm{~m}^{3} / \mathrm{s} . \mathrm{C}_{\mathrm{s}}=93.94 \mathrm{mg} / \mathrm{l}$ (Table 2), $\mathrm{Q}_{\mathrm{s}}=(0.0864)\left(7.0355 \mathrm{~m}^{3} / \mathrm{s}\right)(93.94 \mathrm{mg} / \mathrm{l})=57.1031$ tonnes/day. Calculated water discharge and sediment transport for Mangoase are illustrated in Table 2. 


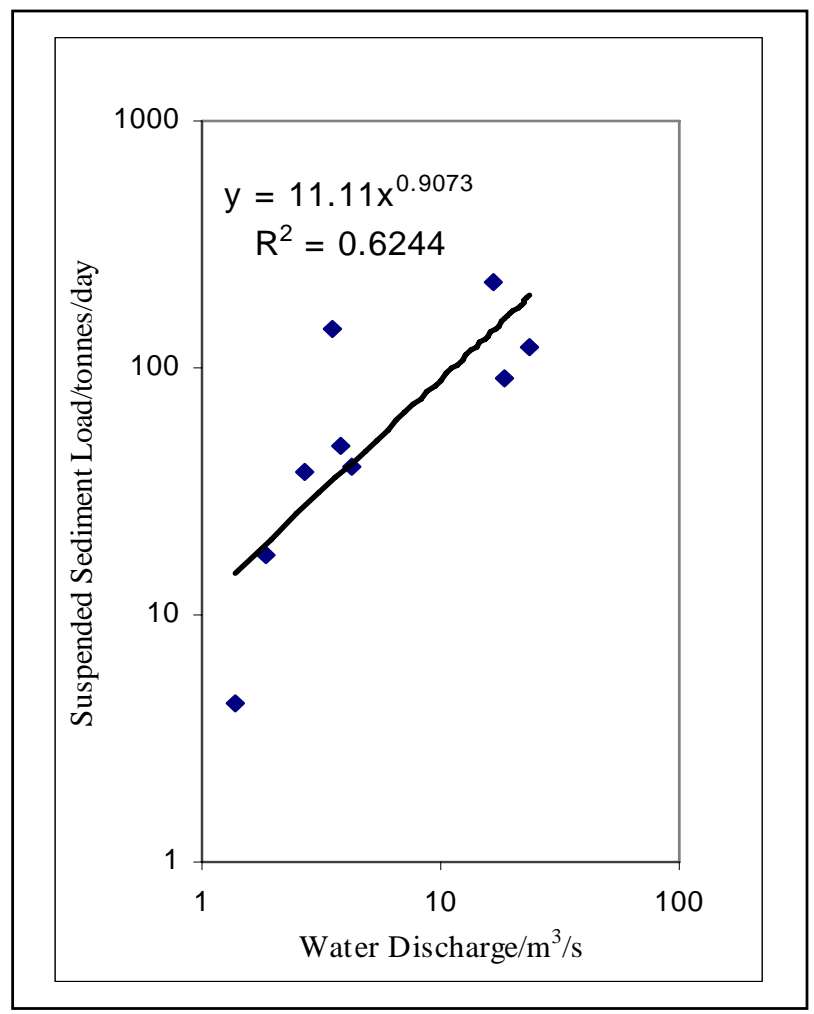

Fig. 7. Sediment rating curve for Ashalaja

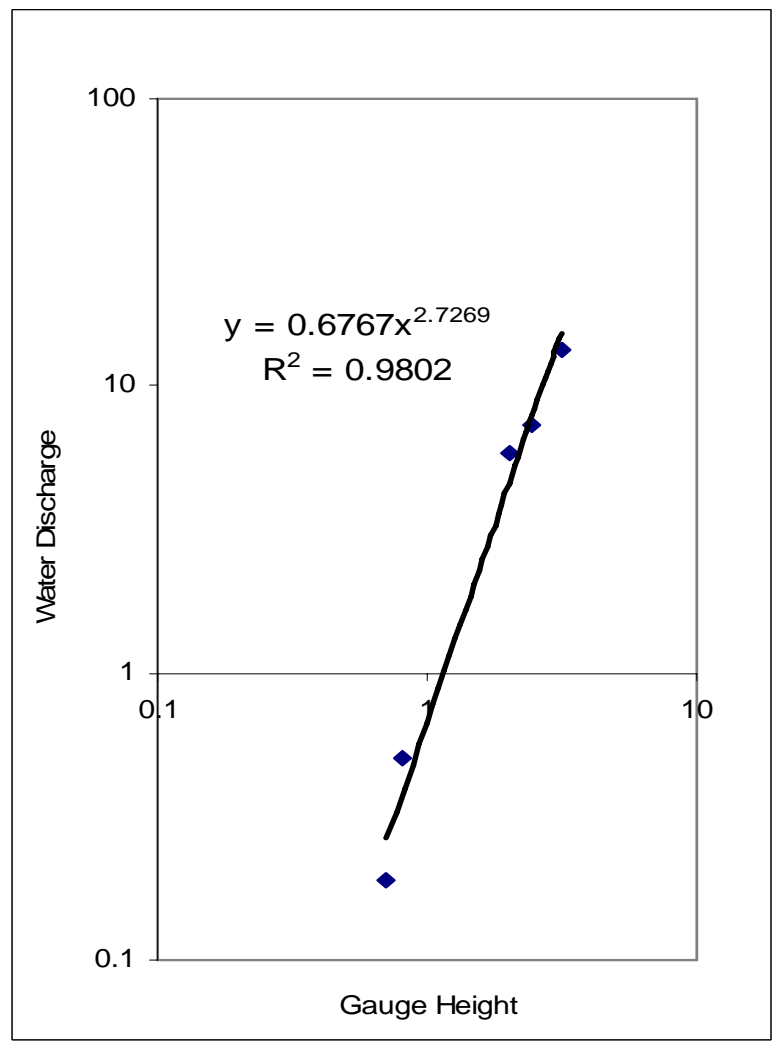

Fig. 8. Discharge rating curve for Mangoase 


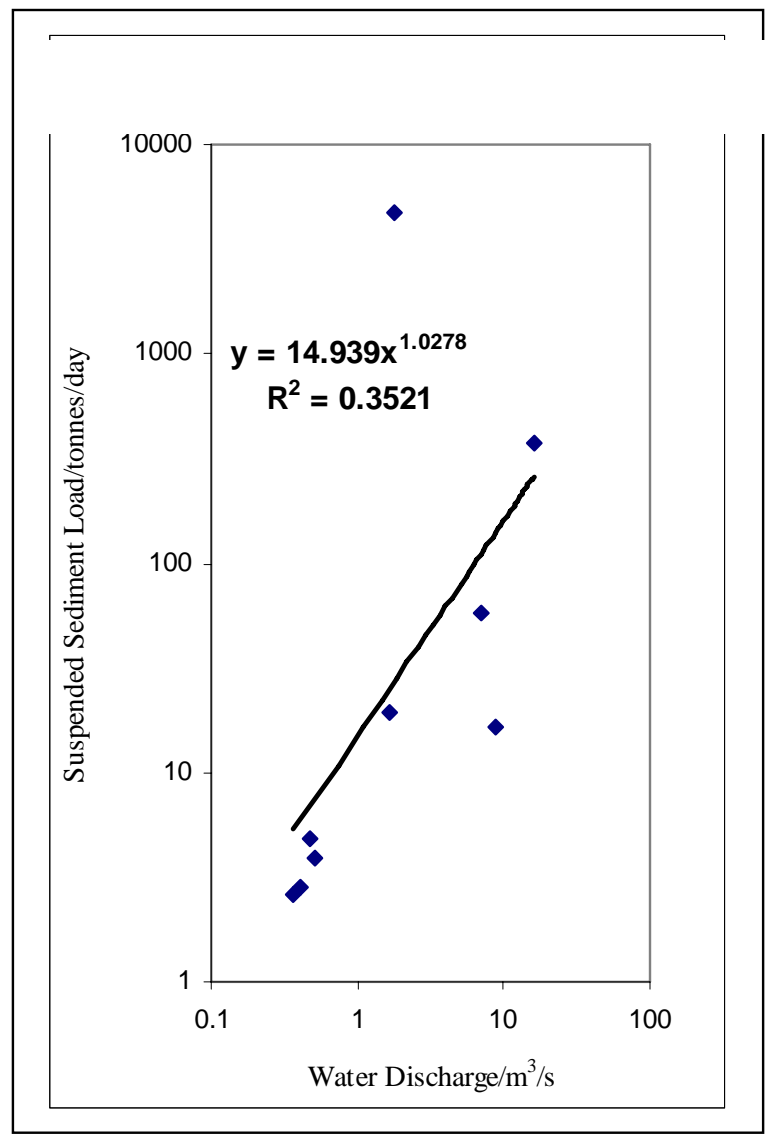

Fig. 9. Sediment rating curve for Mangoase

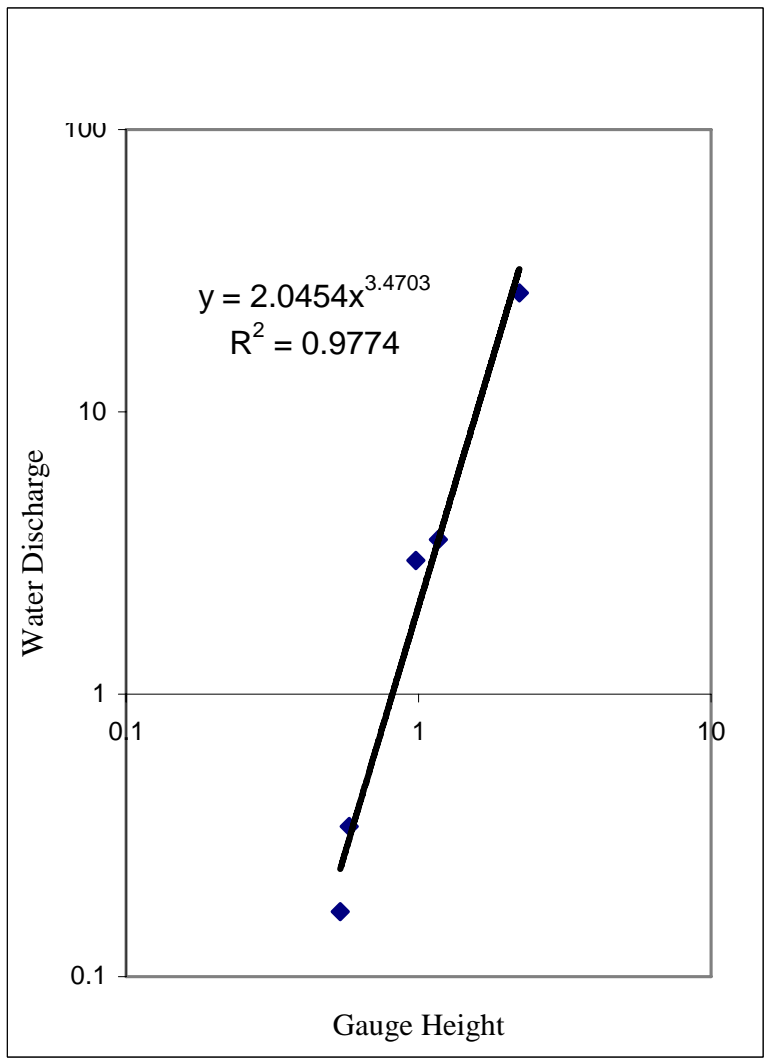

Fig. 10. Discharge rating curve for Akwadum 


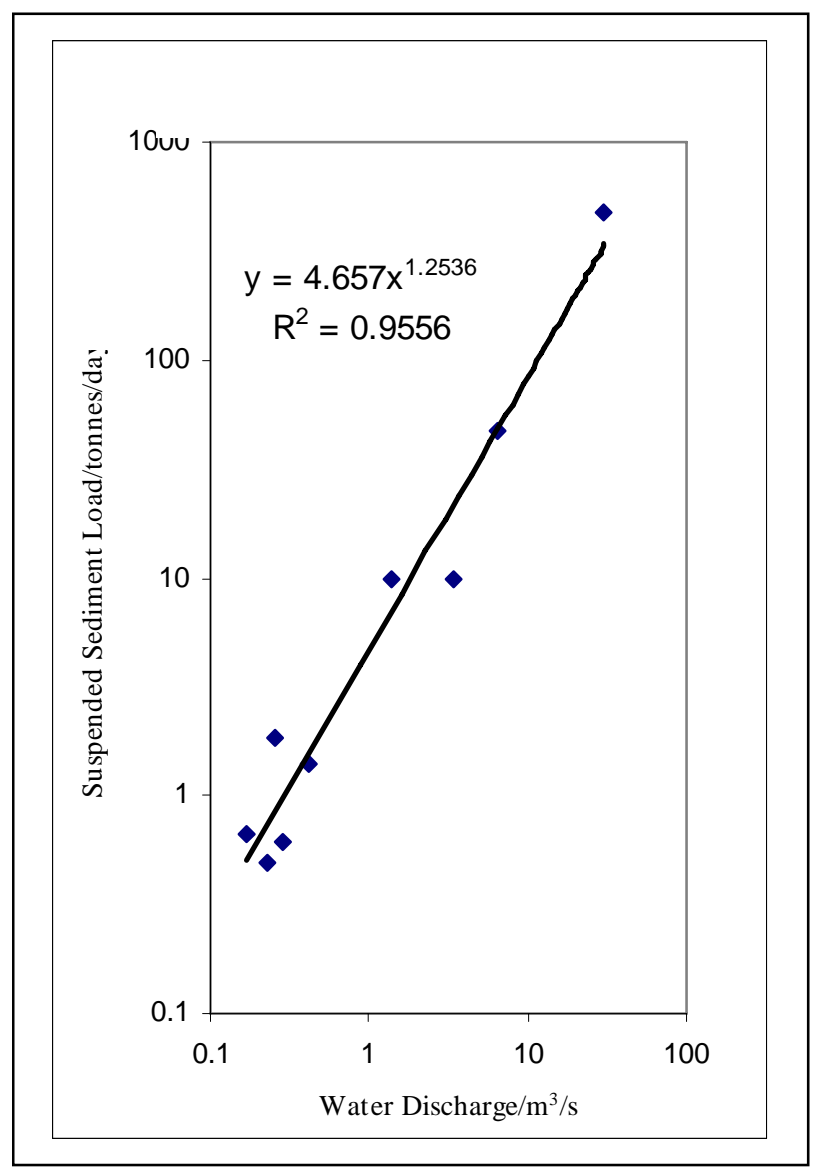

Fig. 11. Sediment rating curve for Akwadum

Akwadum sampling station. Equation of the line $\mathrm{y}=\mathrm{Q}_{\mathrm{w}}=2.0454 \mathrm{x}^{3.4703}$ (Fig.9) where $\mathrm{x}=1.39(\mathrm{~m})$ (Table 3). $\mathrm{Q}_{\mathrm{w}}=(2.0454)(1.39)^{3.4703}=(2.0454)(3.1355)=6.4134 \mathrm{~m}^{3} / \mathrm{s}, \mathrm{C}_{\mathrm{s}}=85.44 \mathrm{mg} / \mathrm{l}$ (Table 3), $\mathrm{Q}_{\mathrm{s}}$ $=(0.0864)\left(6.4134 \mathrm{~m}^{3} / \mathrm{s}\right)(85.44 \mathrm{mg} / \mathrm{l})=47.3438$ tonnes/day. Calculated water discharge and sediment transport for Akwadum are shown in Table 3.

Generally, fluvial sediment transport during high flows was high and low for low stages. The high sediment discharge of 142.335 and 4772.207 tonnes/day recorded at Ashalaja and Mangoase at low flows of $1.19 \mathrm{~m}$ and $1.43 \mathrm{~m}$, respectively, was due to a storm which occurred a few minutes prior to sampling. The highest suspended sediment discharge during high flows was 475.641 tonnes/day at Akwadum at $2.18 \mathrm{~m}$ level, and the lowest sediment discharge was 0.492 tonnes/day at $0.53 \mathrm{~m}$ stage also at Akwadum. The reduction in suspended sediments with a fall in stage (discharge) means that more suspended sediments get settled as bed load as flow reduces. As stated by Bloom (1998), the amount of sediments that will stay in transport as suspended load is a power function of mean velocity. This explains the increasing levels of sand and silt in the bed load as the flow rate reduces.

It was also observed that sediment discharge increases downstream from Akwadum to Ashalaja at both low and high flows. This is attributed to a number of factors such as the reduction in vegetative cover downstream (Fig. 2), implying much erosion by run-off into the river channel, increase in the catchment area (means more eroded materials are brought by tributaries), loose nature of soils (sandy soils are easily eroded), farming within the fringes of the bank and gardening at the floodplain, especially at Nsawam exposing the land surface to erosion by run-off. According to Knighton (1998) materials in which sand and gravel dominate are more liable to erosion than those with high silt-clay content. Also, average rates of bank erosion have been shown to increase with catchment size acting as a surrogate for discharge (Hooke, 1980, Brice, 1984), but the highest 
rates may occur in the middle reaches of rivers where stream power is at its maximum (Lawler, 1992).

Farming (both cash and food crops) and vegetables gardening along the river's bank at Mangoase and Nsawam will have a significant impact on soil erosion as satellite imagery (Fig. 2) indicate a very low biomass cover within this zone. Vegetation in this section of the basin is degraded into grassland and shrubs by anthropogenic forces particularly farming. The poor vegetative cover implies loose sandy soils are more prone to erosion from the short and torrential thunderous rains of the dry equatorial region. With a low overland flow of $0.41 \mathrm{~km}$ and high drainage density of $1.22 \mathrm{~km}^{2} / \mathrm{km}$, eroded sediments are easily entrained into channels ending up in the Densu. These eroded materials are used as tools for wearing away the bank and bed of the river, especially when in flood, giving rise to abraded banks. This accounts for the incised and abraded meanders at Nsawam.

The outer edges of the meanders are abraded whilst the inner bends undergo deposition (lateral accretion), forming point bars and alluvial deposits. These bars are composed of a mixture of bed and suspended materials (force deposition hence ungraded/unsorted), which are vegetated on exposure. The thick vegetative cover of the upper section (wet-semi-deciduous forest), on the other hand, reduces run-off, binds soil particles and, thus, minimizing erosion. Less sediments entrain into river channels in this region. This corroborates the findings of Smith (1976) that bank sediment with a root volume of $16-18 \%$ and a 5 -cm root material was afforded 20,000 times more protection from erosion than comparable sediment without vegetation.

\section{Conclusion}

The Densu river is seriously under threat from various land-use activities within the basin. These are agricultural, indiscriminate waste disposal, as well as building and construction. These activities have gained their roots because of lack of effective implementation and monitoring of water management and environmental policies by local government authorities in all the districts through which the Densu river flows. These practices have impacted very much on the fluvial processes of the river (erosion and deposition), leading to much morphological changes in the channel pattern and form, braiding at the lower section and erosion at the middle course.

Run-off entrains sediments especially sand and silt into the river channel from exposed surfaces, resulting in the siltation of the river bed. Bed load analysis revealed that there was an inverse relationship between flow level and the concentration of sand and silt in the river channel. The concentration of sand and silt was high at low stages and minimal at high flows. Also, sediment discharge was found to be increasing from the source towards the mouth. The implication of sediment load and transport patterns in the river catchment is that it poses a great threat to the sustainability of the Weija Dam and water quality of the river in general. As indicated earlier, the dam is silting up at alarming rate which if not checked will have grave consequences on water supply to the western part of Accra metropolis. Also sediment load affects water turbidity. Turbidity determines the degree of scattering or absorption of light in the water and, thus, influences water temperature and the growth of aquatic plants and algae, which can increase water loss (evapo-transpiration) or cause eutrophication.

\section{Recommendations}

In the light of the above findings, a number of suggestions have been put forward to aid or guide river basin management policies or studies of this kind, particularly on the Densu basin.

Sediment load analysis of the kind conducted in this project is inadequate in assessing or predicting sediment yield of the basin as it was within a very short duration. A much longer and continuous period of three or more years of the Densu river sediment load analysis is recommended to get reliable data on the erosion and sediment rates within the basin. Detailed land-use studies of the basin needs to be accessed along side with sediment analysis so as to be in a better position to 
appreciate the extent, dimension and the key driving forces of erosion within the river catchment. With this, one will be in a better position to advise and inform policy makers on the best basin management practices/policies that need to be adopted within this basin.

In view of the immense contributions of the Densu river and its tributaries to the livelihood of the people within its catchment including Accra West, certain water management practices should be adopted by both central and local governments to save the Densu river. The setting up of the Densu River Management Board by the Government is a good initiative but such a body should be more proactive and vibrant in monitoring land-use activities within the basin, especially those that exceed the buffer zone. This body should not only be centrally constituted, but have members drawn from all the districts through which the Densu river flows. The board should be resourced by local and central governments, and efforts should be made to seek funding from Non-Governmental Organizations (NGOs) and international organizations to ensure the effective monitoring and implementation of policies by the Board.

Community involvement in all decisions bordering water management in the basin should be adopted to ensure acceptance and compliance with policies. This should be backed by sustainable public education on natural resource management within the Densu. Incentives in the form of awards to people who undertake good environmental management practices within the basin by the district assemblies could also help curb the indiscriminate environmental problems facing the basin. Lastly, institutional and legal reforms of instruments as well as their effective implementation by local authorities on water management could be promulgated towards good river basin management.

\section{Acknowledgement}

The study is an extract of the MPhil. thesis of the author, which was funded by the Water Resources Commission, Accra. The author wishes to express his sincere gratitude to staff of the CSIR-Water Research Institute, Accra, for their assistance in the field data collection and laboratory analysis. He also wishes to thank Prof L. A. Dei (University of Cape Coast) and Mr T. W. Awadzi (University of Ghana) for their invaluable contributions towards the completion of the thesis.

\section{References}

Adu S. and Asiamah R. (1992). Soils of the Ayensu-Densu Basin: Central, Eastern and Greater Accra Regions, Ghana. Soil Research Institute (CSIR), Kwadaso-Kumasi. Memoir No. 9.

Akuffo S. B. (2003). The Imminent Water Supply Crisis in Accra: The Silting Up of the Weija Lake, Accra Mail, Accra, 16 Jan. 2003.

Ayibotele N. B. and Tuffour-Darko T. (1979). Sediment Loads in the Southern Rivers of Ghana. Water Resource Unit (CSIR), Accra.

Brice J. C. (1984). Planform Properties of Meandering Rivers. In River Meandering. New Orleans. (C. M. Elliot, ed.), pp. 1-15. American Society of Civil Engineers,

Bloom A. L. (1998). Geomorphology: A Systematic Analysis of Late Cainozoic Landforms. Prentice Hall, Upper Saddle, New Jersey.

Dickson K. and Benneh G. (1988). A New Geography of Ghana. Longman, London, U. K.

Ghana Statistical Service (2002). 2000 Population and Housing Census. Accra.

Ghana Water Sewerage Company (2003). ATMA. Accra.

Hooke J. M. (1980). Magnitude and Distribution of Rates of River Bank Erosion. Earth Surf. Processes 5: 143-157.

Jensen J. R. (1996). Introductory Digital Image Processing: A Remote Sensing Perspective. Prentice Hall, Upper Saddle River, New Jersey.

Knighton D. (1998). Fluvial Form and Processes: A New Perspective. Edward Arnold Ltd, London.

Lawler D. M. (1992). Process Dominance in Bank Erosion Systems. In Lowland Floodplain Rivers. (P. A. Carling. and G. E. Petts, ed.), pp.117-143. Wiley, Chichester.

Osten A. T. (1979). Sediment Transport in Streams: Sampling, Analysis and Computation, Man. Proc. opl Hydrol. 5. Ministry of Water Energy and Minerals (Tanzania) and Norwegian Agency for International Development (NORAD).

Smith D. G. (1976). Effect of Vegetation on Lateral Migration of Anastomosed Channels of Glacier Meltwater River. Bull. Geol. Soc. Am. 87: 857-860. 